\title{
Youth and children's public associations of Yaroslavl: state, activities and prospects for the development of the public sector
}

\author{
M. V. Ivanov ${ }^{1}$ \\ 1MAI “INDSI", 8 Maximova str., Yaroslavl 150000, Russian Federation
}

DOI: $10.18255 / 2412-6519-2020-3-260-273$

Research Article

Full text in Russian

The article presents the results of a comprehensive sociological study of the Yaroslavl youth movements, associations, as well as informal groups and their participation in the life of the city. 500 Yaroslavl citizens aged 14 to 35 were interviewed. The level of awareness of Yaroslavl youth about youth organizations, movements and movements, including operating in the city, the degree of involvement of young citizens in these organizations was assessed. Modern youth is poorly absorbing the difference between formalized public youth organizations and informal youth groups. Yaroslavl youth is rather apolitical. In the youth sector, military-patriotic and volunteer trends are developed and popular. Organizations of this orientation have a high recognition rating. If we compare formal and informal youth groups, then the Yaroslavl youth is most informed about the latter. Almost $60 \%$ of youth organizations and movements, according to their members, take part in the public life of the city. Most often, such participation is limited to involvement in citywide events, holidays and promotions (32\%), as well as in the creation of performances that affect the urban environment and public life (30\%). Potentially, one can try to attract from 70 to $84 \%$ of participants in youth associations of Yaroslavl to socially significant activities. The main points of application of their labor for the benefit of the city, youth sees social labor, creative, search and rescue and scientific activities.

Keywords: youth; youth associations; informal groups; participation; involvement; motivation; social life

INFORMATION ABOUT THE AUTHORS

\begin{tabular}{l|l} 
Ivanov Mikhail V. & $\begin{array}{l}\text { E-mail: ivanovmv@indsi.ru } \\
\text { Head of Analytical and Sociological Research }\end{array}$
\end{tabular}

For citation: Ivanov M. V. Youth and children's public associations of Yaroslavl: state, activities and prospects for the development of the public sector // Social'nye i gumanitarnye znanija. 2029. Vol. 6, No 3. P. 260-273.

(in Russ.) 


\title{
Молодежные и детские общественные объединения Ярославля: состояние, участие, перспективы развития общественного сектора
}

\author{
М. В. Иванов ${ }^{1}$ \\ ${ }^{1}$ МАУ «ИРСИ», ул. Максимова, 8, Ярославль, 150000, Российская Федерация
}

DOI: $10.18255 / 2412-6519-2020-3-260-273$

УдК 316.353

Научная статья

Полный текст на русском языке

В статье изложены результаты комплексного социологического исследования ярославских молодежных движений, объединений, а также неформальных групп и их участие в жизни города. Были опрошены 500 ярославцев в возрасте от 14 до 35 лет. Исследовались уровень информированности ярославской молодёжи о молодёжных организациях, движениях и течениях, в т. ч. действующих на территории города, оценивалась степень вовлеченности молодых горожан в данные организации. Современная молодёжь плохо усваивает разницу между формализованными общественными молодёжными организациями и неформальными молодёжными группами. Ярославская молодёжь достаточно аполитична. В молодёжном секторе развиты и популярны военно-патриотическое и волонтерское направления. Организации этой направленности имеют высокий рейтинг узнаваемости. Если сравнивать формальные и неформальные молодёжные группы, то ярославская молодёжь наиболее информирована о вторых. Почти 60 \% молодёжных организаций и движений, по мнению их членов, принимают участие в общественной жизни города. Чаще всего такое участие ограничивается вовлеченностью в общегородские мероприятия, праздники и акции (32\%), а также в создание перфомансов, которые влияют на городскую среду и общественную жизнь (30\%). Потенциально к общественнозначимой деятельности можно попытаться привлечь от 70 до 84 \% участников молодежных объединений Ярославля. Основными точками приложения своего труда на благо города молодёжь видит общественно-трудовую, творческую, поисково-спасательную и научную деятельность.

Ключевые слова: концептуализация детства; гендерная роль; гендерная социализация; гендерный контракт; феминность

ИНФОРМАЦИЯ ОБ АВТОРАХ

Иванов Михаил Владимирович

Email: ivanovmv@indsi.ru

Начальник отдела аналитических и социологических исследований

Для цитирования: Иванов М. В. Молодежные и детские общественные объединения Ярославля: состояние, участие, перспективы развития общественного сектора // Социальные и гуманитарные знания. 2020. Том 6, № 3. С. 260-273.

(C) Иванов М. В., 2020

This is an open access article under the CC BY-NC-ND license (http://creativecommons.org/licenses/by-nc-nd/4.0/) 


\section{Введение}

Несмотря на то, что проблема молодёжи рассматривается и изучается уже не первое десятилетие, ни в общественных науках, ни в государственно-правовой практике до сих пор нет четкого подхода к определению этого понятия. Более того, отсутствуют даже элементарные временные рамки, которые бы содержательно конкретизировали данный термин [1, с. 19].

Обычно в социологии к категории «молодежь» принято относить молодых людей в возрасте от 16 до 30 лет. Вместе с тем в зависимости от правовых, социально-экономических, политических, культурных и других факторов нижняя и верхняя границы её могут быть сдвинуты. Так, например, Всемирная программа действий в интересах молодежи Организации Объединенных Наций определяет молодежь как людей в возрасте от 15 до 24 лет ${ }^{1}$. В Российской Федерации (а до этого в СССР) большинство ученых к молодежи причисляли лиц в возрасте от 15 до 29 лет, условно выделяя такие возрастные когорты, как: подростки - до 18 лет, собственно «молодежь» - 18-24 года и «молодые взрослые» - 25-29 лет.

Стратегия развития молодежи Российской Федерации на период до 2025 года определяет временные рамки «молодёжи» от 14 до 30 лет. В случаях, когда речь идет об официальных документах, то есть о правовом статусе данной социальной группы, важны четкие границы молодежного возраста. Это прежде всего необходимо для того, чтобы определить тех, кому государство хочет оказать поддержку. Например, при разработке государственных программ для молодежи по льготным кредитам на приобретение жилья. В федеральном законодательстве до сих пор пока нет специальных правовых норм, кого считать «молодежью» [2, с. 16-17; 4, с. 85-86].

В ряде субъектов РФ [3] такие нормы есть, в частности, если касаться вопросов предоставления жилья для молодых семей, то многие регионы и муниципальные образования уже давно отодвинули верхнюю границу для молодёжи до 35 лет ${ }^{2}$ и активно ратуют за то, чтобы поднять её и до 40 лет $^{3}$.

За последние десятилетия физическое, в частности половое, созревание индивидов заметно ускорилось, что закономерно привело к снижению границы юношеского возраста. Напротив, усложнение общественно-трудовой, интеллектуальной деятельности, в которой должен участвовать человек, повлекло за собой увеличение сроков, необходимых для обучения. Новое поколение молодежи значи-

\footnotetext{
1 Общепризнанного международного определения возрастной группы «молодежь» не существует. Однако для статистических целей Организация Объединенных Наций без ущерба для любых других определений, данных государствами-членами, определяет «молодежь» как лиц в возрасте от 15 до 24 лет. Это определение, которое появилось в контексте подготовки к Международному году молодежи (1985 год), было одобрено Генеральной Ассамблеей в ее резолюции 36/28 от 1981 года. Все статистические данные ООН по молодежи основаны на этом определении, что отражено в ежегодных статистических ежегодниках, публикуемых системой ООН по демографии, образованию, занятости и здравоохранению. См. Доклад о мировом развитии. 2007 // Развитие и новое поколение. М., 2007. С. 31.

${ }^{2}$ Например, в Ярославской, Московской, Курской, Рязанской, Нижегородской, Саратовской, Кемеровской, Свердловской, Тюменской, Омской областях, Алтайском и Ставропольском краях и т. д.

${ }^{3}$ Глава ЯНАО Д. Артюхов дал поручение проработать вопрос о поднятии предельного возраста для молодых семей до 36 лет, а в соседнем ХМАО депутат регионального заксобрания на прямой линии с президентом В. Путиным выступил с инициативой поднять возрастные рамки до 40 лет.
} 
тельно позже начинает трудовую жизнь, чем их ровесники в прошлом, дольше сидит за школьными партами. Большинство после школы продолжает учебу. Поэтому, руководствуясь соображениями адекватного и объективного представления проблемы, мы в проведенном исследовании считали «молодёжью» людей в возрасте от 14 до 35 лет.

\section{Исследования по теме}

В последние годы органы власти всё чаще и чаще обращают внимание на новые подходы к формированию современного молодого поколения: молодежь рассматривается как некий стратегический ресурс, как дополнительная мобильная и малозатратная общественная сила настоящего и будущего развития страны. Молодежь является носительницей значительного инновационного потенциала, который может при активном его востребовании содействовать общественным преобразованиям. Молодёжь всё чаще начинает восприниматься не только как объект, но и как полноправный субъект общественно-политической, экономической и социокультурной деятельности [4, с. 213]. Однако, как справедливо отмечают М. С. Безбогова и М. В. Ионцева, «несмотря на свое желание коммуницировать и быть в социуме, они [молодёжь] склонны к индивидуализму, им важно выразить свою точку зрения и обозначить свое место в мире» [5, с. 7]. Такое стремление молодежи к общественному участию осуществляется, как правило, через деятельность в молодежных общественных организациях и объединениях.

В отношении молодёжных организаций и объединений также не существует устоявшихся единых понятий, критериев и определений. Так, в научной литературе по социально-культурной деятельности одновременно рассматриваются и используются различные формы активности молодежи, такие как: «молодежная организация», «молодежное общественное движение», «молодежное общественная организация», «молодежное сообщество», «молодежное объединение», «молодежное общественное объединение».

Молодежные объединения, как подчеркивает С. Б. Бурбаева, имеют ряд конкретных характеристик:

- некоммерческая направленность деятельности;

- безусловная добровольность членства;

- развитая система традиций, символики, ритуалов, правил и норм жизни, что создаёт неповторимый облик объединения;

- возможность самостоятельно (без вмешательства извне) определять и реализовывать принципы своей жизнедеятельности, содержание и формы своей деятельности;

- гуманистический (уважительный, внимательный по отношению к человеку) стиль отношений в объединении [6, с. 226].

Часть данных характеристик применима и для выделения специфических черт современных молодёжных субкультур. Так, О. В. Власова относит к таким признакам:

- требование к участникам придерживаться определённого стиля, который внешне реализуется в общении, символике, сленге, музыкальных увлечениях, моде;

- неоднородность составляющих её культурных компонентов, неустойчивость как социального явления;

- ориентированность на досуг и коммуницирование; 
- социальное окружение и его характеристики (социальный состав семьи, уровень образования и возраст её членов) [7, с. 92].

Специфика современных процессов строительства и развития детских и молодёжных организаций и объединений заключается в том, что идет, с одной стороны, попытка государства и властных институтов взять этот процесс под управление и сделать его контролируемым, но в то же время, с другой стороны, и сама молодёжь, самоорганизуясь в свои объединения и группы по интересам, отнюдь не стремится влиться в те форматы, которые предлагает власть, более того, есть основания говорить об аполитичности нынешней молодёжи [8, с. 10]. По словам И. М. Ильинского и В. А. Лукова, проанализировавших возможности и перспективы государственного строительства массовой молодёжной организации всероссийского масштаба, «в этих условиях необходимо особенно бережно относиться к автономности «третьего сектора» по отношению к государству и учитывать естественные процессы развития гражданского общества, включая и молодежное движение» [Там же. С. 19-20]. Поэтому перед властью поставлена трудная задача - найти приемлемые форматы и векторы эффективного взаимодействия молодёжи, власти и общества. Причем ситуация усугубляется ещё и тем, что в «государстве нет чёткого понимания того, для чего нужны такие [детские и молодёжные] организации, какая помощь им необходима и как грамотно взаимодействовать с ними для обоюдной пользы» [9, с. 171].

Этой же логикой пользуется и О.А. Родина, обосновывающая тот факт, что «объединения, созданные для достижения утилитарных целей властных или бизнес-кругов, а не для реализации актуальных потребностей общества и молодежи, по определению неэффективны» [10, с. 16].

При этом, как справедливо отмечает А. В. Кострикин, «молодежные объединения, как и вообще некоммерческие организации, сами стоят перед проблемой самоидентификации» [11, с. 182]. В частности, они должны сделать выбор между пониманием своей деятельности либо в качестве поставщиков услуг, либо - структур, формирующих ценностные ориентации. В связи с этим в широком понимании молодёжные объединения охватывают совокупность различных форм активности молодёжи от неформальных групп по интересам до формально организованных и юридически оформленных структур. Основная направленность их деятельности связана, с одной стороны, с реализацией «стремления молодежи к самоактуализации, обретению социальной субъектности» [12, с. 51]. С другой стороны, молодежные объединения призваны способствовать усилиям общества и государства «по мобилизации, управлению и контролю молодежи в социально желаемом и социально приемлемом русле» [Там же]. В связи с этим можем согласиться с мнением Е. В. Великановой о том, что «современным молодежным движениям не обойтись без поддержки государства, а молодежному общественному движению - без общественной поддержки» $[13$, с. 150].

При этом необходимо учитывать и понимать, что на государственно-правовом уровне вне зоны воздействия, а следовательно, и господдержки остаются:

- молодежные и детские коммерческие организации;

- молодежные и детские религиозные организации;

- молодежные и студенческие объединения, являющиеся профессиональными союзами; 
- молодежные и детские объединения, учреждаемые либо создаваемые политическими партиями ${ }^{1}$.

В то же время непосредственными объектами господдержки выступают только зарегистрированные в установленном законом порядке молодежные объединения граждан в возрасте до 30 лет, объединившихся на основе общности интересов при соблюдении ими следующих условий:

- объединение является юридическим лицом и действует не менее одного года с момента его государственной регистрации;

- в объединении насчитывается не менее 3000 членов².

В опросе, проводимом МАУ «ИРСИ», молодёжные общественные объединения мы понимали в более широком контексте. А именно как совокупность различных форм (вне зависимости от их правового статуса) взаимодействий и активностей молодых людей (в возрасте от 14 до 35 лет), формируемую ими на основе общих интересов и социальной практики в целях удовлетворения потребностей в самореализации, осуществлении прав и свобод на принципах добровольности и самоуправления.

\section{Методы}

По заявке Управления по молодежной политике мэрии г. Ярославля № 0109/1193 от 21.12.2018 специалисты МАУ «ИРСИ» в августе 2019 г. провели опрос, посвященный изучению и оценке состояния и развитости детских и молодежных движений, объединений, а также неформальных групп и их участие в жизни города.

Для реализации поставленной цели были выдвинуты следующие задачи:

- - выявить уровень информированности ярославской молодёжи о молодёжных организациях, движениях и течениях, в т. ч. действующих на территории города;

- - оценить степень вовлеченности ярославцев в деятельность молодёжных организаций;

- - проанализировать основные мотивы и способы вступления в молодёжные организации;

- - охарактеризовать участие молодёжных движений и организаций в общественной жизни города;

- - определить отношение молодёжи к деструктивным молодёжным течениям.

В рамках исследования были опрошены 500 ярославцев в возрасте от 14 до 35 лет. Выборка случайная, бесповторная и статистически репрезентативная по полу, возрасту и районам проживания. Ошибка выборки не превышает 4,5 \%.

\section{Результаты}

Согласно полученным нами данным, около половины опрошенных молодых ярославцев (46 \%) отметили, что знают о наличии в городе молодёжных формальных и неформальных объединений, но в то же время почти каждый второй из них

\footnotetext{
${ }^{1}$ См. п. 2 ст. 1 Федерального закона «О государственной поддержке молодежных и детских общественных объединений» № 98-ФЗ от 28.06.1995.

${ }^{2}$ См. п. 1 и 2 ст. 4 Федерального закона «О государственной поддержке молодежных и детских общественных объединений» № 98-ФЗ от 28.06.1995 (в ред. Федерального закона от 22.08.2004 № 122-Ф3).
} 
(47 \%) не смог навскидку привести ни одного названия. Таким образом, объективно только примерно каждый четвертый (24\%) респондент реально информирован о деятельности молодёжных общественных организаций в городе.

В числе наиболее популярных ответов чаще всего упоминались такие молодёжные объединения, как молодёжное трудовое движение «ЯрОтряд» (его отметили 22,5 \% опрошенных), ЛГБТ-сообщество (6,5 \%), «Союз студентов» (6\%), сообщества «анимешников» (6 \%), «Молодой Ярославль» $(5,6$ \%), панк-движение $(4,3$ \%) и набирающее обороты молодёжное движение К-попперов $(3,9 \%)$.

Что интересно, в своих ответах респонденты упоминали как формализованные, юридически оформленные организации (например, движения «ЯрОтряд» и «Молодой Ярославль», организации «Союз студентов», РСМ, поисково-спасательный отряд «ЯрСпас»), так и неформальные группы и движения. Причем в отношении последних конкретные названия звучали реже, в основном их определяли с точки зрения тематики и ценностно-культурных ориентаций и молодёжных субкультур (например, ЛГБТ, «анимешники», К-попперы, «панки», «эмо», «готы», «блогеры», «ютуберы» и т. д.).

Говоря о формальных молодёжных организациях и объединениях, мы отметили, что им оказывает поддержку государство. Также есть целый ряд организаций, которым оказывается поддержка на уровне города и области. Большинство из них собраны в «Реестр общественных организаций города Ярославля». На основании данного Реестра и частоты упоминаемости в местных СМИ мы составили список из примерно двух десятков молодёжных и детских общественных объединений и попросили молодых ярославцев выбрать те, о которых они что-то слышали либо знают.

Как видно из полученных результатов, список организаций и объединений получился достаточно полный - лишь 4 \% опрошенных отметили, что не знают / не слышали ничего ни об одной из перечисленных организаций. При этом пятерку лидеров составили всё те же организации, которые были названы респондентами навскидку, а именно: молодёжное трудовое движение «ЯрОтряд» (53 \%), «Союз студентов» (50\%), «Молодой Ярославль» (38\%), Российский Союз молодёжи/РСМ (35 \%) и поисково-спасательный отряд «Ярспас» (32\%).

Основываясь на анализе основных направлений деятельности представленных в списке молодежных общественных объединений, мы разделили их на пять условных типов (см. таблицу 1).

Самую большую группу составили молодёжные движения общественно-политической направленности. Сюда мы включили профсоюзные молодёжные организации и объединения («Союз студентов», «Российский союз молодёжи», Городской координационный совет старшеклассников), а также политические («Молодая гвардия Единой России») и общественно-политические организации («Молодёжный совет г. Ярославля», «Молодёжная палата Ярославской области»). Наибольшим рейтингом узнаваемости среди этих молодёжных объединений обладает «Союз Студентов» и его дочерние организации - 50 \%, наименьшим - Городской координационный совет старшеклассников - $18 \%$.

Вторую большую группу образуют молодёжные движения военно-патриотической направленности. К их числу мы отнесли Общественное движение «Юнармия»; Военно-патриотический клуб «Десантник» им. гвардии сержанта ВДВ 
Л. Палачева и Ярославскую региональную военно-патриотическую молодежную общественную организацию «Гвардия». Рейтинг узнаваемости этих организаций в принципе достигает средней величины и сопоставим (порядка 23-25 \%).

В третью группу вошли волонтерские молодежные объединения. Основные направления деятельности данных организаций - поисковая и поисково-спасательная деятельность, экологическая и военно-патриотическая направленность. Наибольшим рейтингом узнаваемости пользуется отряд «ЯрСпас» (32 \%), наименьшим - поисковый отряд «Группа «Поиск»» $(11 \%)$.

Таблища 1

\section{Типология молодежных и детских общественных организаций и движений}

\begin{tabular}{|c|c|}
\hline Направления деятельности & Молодёжные объединения \\
\hline $\begin{array}{l}\text { Общественно-политическое } \\
\text { (рейтинг от } 18 \% \text { до } 50 \% \text { ) }\end{array}$ & $\begin{array}{l}\text { Союз Студентов; } \\
\text { Российский Союз молодёжи (РСМ); } \\
\text { Молодежный совет г. Ярославля; } \\
\text { Молодая гвардия «Единой России»; } \\
\text { Молодежная палата ЯО; } \\
\text { Городской координационный совет старшеклассников }\end{array}$ \\
\hline $\begin{array}{l}\text { Военно-патриотическое } \\
\text { (рейтинг от } 23 \% \text { до } 25 \% \text { ) }\end{array}$ & $\begin{array}{l}\text { Общественное движение «Юнармия»; } \\
\text { Военно-патриотический клуб «Десантник» им. гвардии } \\
\text { сержанта ВДВ Л. Палачева; } \\
\text { Ярославская региональная военно-патриотическая } \\
\text { молодежная общественная организация «Гвардия» }\end{array}$ \\
\hline $\begin{array}{l}\text { Волонтерское } \\
\text { (рейтинг от } 11 \% \text { до } 32 \text { \%) }\end{array}$ & $\begin{array}{l}\text { Поисково-спасательный отряд «Ярспас»; } \\
\text { Поисковый отряд «Высота 76»; } \\
\text { Волонтерское движение «Экодесант»; } \\
\text { Поисковый отряд «Группа "Поиск"» }\end{array}$ \\
\hline $\begin{array}{l}\text { Профориентационное } \\
\text { (рейтинг от } 10 \text { \% до } 53 \text { \%) }\end{array}$ & $\begin{array}{l}\text { Молодёжное трудовое движение «ЯрОтряд»; } \\
\text { Движение «Юные друзья полиции»; } \\
\text { «Содружество детей Ярославии»; } \\
\text { Ассоциация молодых профессионалов }\end{array}$ \\
\hline $\begin{array}{l}\text { Досугово-клубное } \\
\text { (рейтинг от } 10 \% \text { до } 38 \% \text { ) }\end{array}$ & $\begin{array}{l}\text { «Молодой Ярославль»; } \\
\text { Ярославский клуб интеллектуальных игр «Яркий» }\end{array}$ \\
\hline
\end{tabular}

Четвертую группу молодёжных объединений сформировали профориентационные молодёжные организации. К ним мы отнесли Молодёжное трудовое движение «ЯрОтряд»; движение «Юные друзья полиции»; «Содружество детей Ярославии» и Ассоциацию молодых профессионалов. Наибольшим рейтингом узнаваемости пользуется «ЯрОтряд» (32 \%), наименьшим - поисковый отряд «Группа «Поиск»» $(11 \%)$.

И, наконец, в пятую группу молодежных объединений вошли досугово-клубные молодёжные организации. В их число мы включили движение «Молодой Ярославль» с рейтингом узнаваемости в 38 \% и Ярославский клуб интеллектуальных игр «Яркий» $(10 \%)$.

По аналогии с перечнем условно «формальных» молодёжных объединений нами также был подготовлен список из наиболее часто упоминаемых в соцсетях и СМИ перечень неформальных молодёжных групп и движений, причем некоторые группы были укрупнены и объединены, чтобы можно было представить как можно больше молодёжных групп, движений и субкультур. Молодым респондентам был 
задан всё тот же вопрос: Какие из представленных групп и движений, существующих на территории города, вам известны?

Лидерство в этом рейтинге узнаваемости поделили «анимешники» и борцы за здоровый образ жизни (т. н. 30Жники), набравшие по 69 \%. Также в топ-5 вошли «блогеры», «стримеры», «ютуберы»- 65 \%, представители ЛГБТ-сообществ - 62 \% и «геймеры» - $59 \%$.

Если сравнивать процент узнаваемости неформальных групп и объединений из перечня «формальных», то сразу в глаза бросаются две особенности. Во-первых, высокий рейтинг узнаваемости неформальных объединений: из семнадцати позиций рейтинга только четыре имеют рейтинг узнаваемости ниже 30 \%. Напомним, что в рейтинге «формальных» объединений из девятнадцати организаций выше 30 \% рейтинг узнаваемости был лишь у пяти. И, во-вторых, высокая плотность результатов «неформалов», что может говорить о достаточно развитых и разнообразных интересах и познаниях молодых ярославцев о неформальных объединениях и современной молодёжной субкультуре. Однако для того, чтобы исследовать глубину и характер этих интересов, было бы правильно оценить степень охвата молодежи данными объединениями.

Для оценки степени вовлеченности молодых ярославцев в деятельность молодёжных организаций и объединений респондентам был задан вопрос: «Являетесь ли Вы (или Ваши знакомые, друзья) участником какого-либо детского или молодёжного объединения, группы?». По итогам полученных ответов оказалось, что 25 \% опрошенных являются членами той или иной молодёжной группы или объединения, а ещё у 21 \% таковыми являются их близкое окружение (друзья и знакомые). Ещё $5 \%$ не вовлечены в деятельность организаций, но хотели бы стать их участниками.

То есть предварительно потенциал вовлеченности молодых ярославцев в молодёжные организации и объединения можно оценить в 46-51\%. Но поскольку данный вопрос задавался только тем представителям молодежи, которые заявили о том, что знают о существовании в городе детских и молодежных объединений и организаций (а таких, напомним, оказалось 46 \%), то в масштабах всей ярославской молодёжи показатель вовлеченности реально будет гораздо ниже и составит порядка 21-23 \%. Иными словами, каждый пятый молодой ярославец в возрасте от 14 до 35 лет является участником какого-либо молодёжного объединения, движения или неформальной группы.

Для понимания того, каковы место и роль молодёжных общественных объединений в жизни современного Ярославля, важно понять, каковы основные мотивы создания этих объединений и вступления в них (см. диаграмму 1).

Как можно заметить, большинство мотивов имеет ярко выраженный эгоистичный, утилитарный характер и заточено сугубо на личности молодых жителей города. Единственный мотив, оперирующий понятием общественного блага, имеет средний показатель в 31 \% и к числу значимых не относится. Ведущими мотивами, лежащими в основе вступления молодёжи в организации и объединения, по её мнению, являются: поиск новых знакомств (64\%), возможность самореализации (59 \%) и проведение досуга (53 \%). Данные проведенного исследования в этой части хорошо корреспондируются с аналогичным исследованием молодёжных объединений города Самары, где в числе доминирующих мотивов участия были названы те же возможность для самореализации и фактор общения с друзьями и знакомыми $[14$, с. 85$]$. 


\section{Основные мотивы создания и вступления в молодежные организации (в процентах от числа опрошенных) ${ }^{1}$}

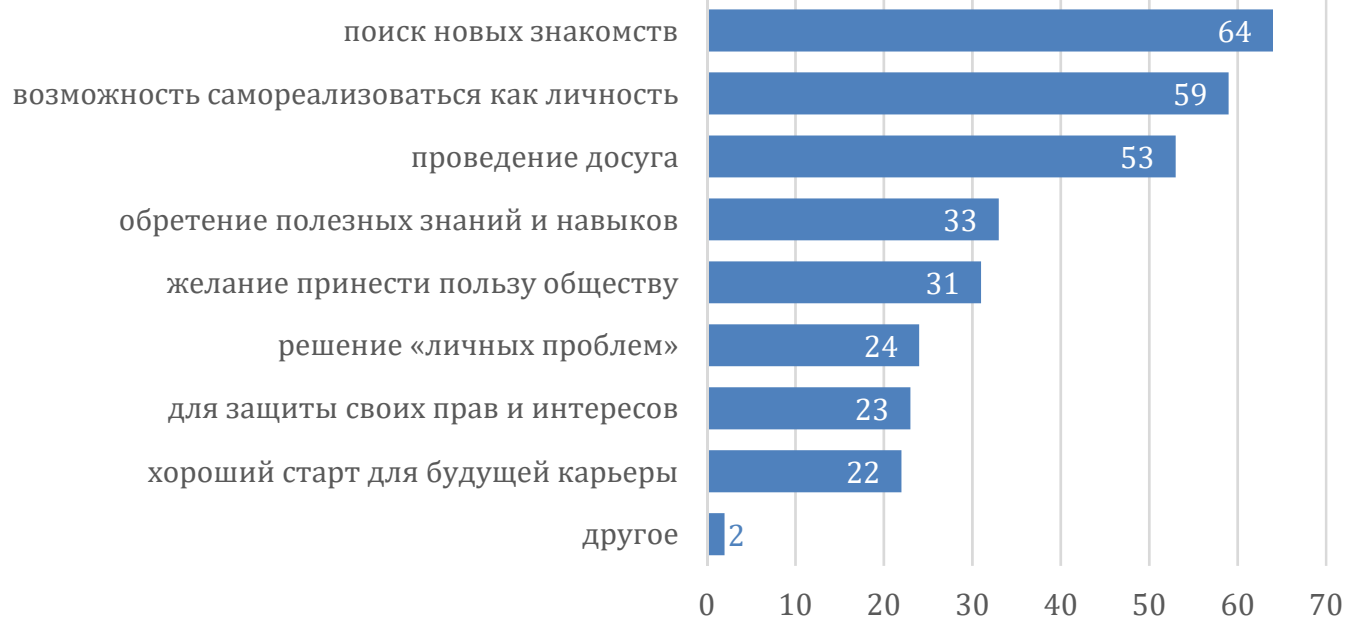

Вместе с тем признание приоритета личного над общественным в мотивации современной молодёжи отнюдь не означает, что ей безразлично то, как живет общество и что молодёжь не хочет ему помочь - всё-таки почти каждый третий молодой человек отметил, что желает принести пользу. Поэтому при работе с молодёжью, с молодёжными организациями и объединениями необходимо понимать, что в первую очередь она ждет удовлетворения своих потребностей, а уже затем требовать с неё решения общественно-значимых проблем. Современная молодёжь это поколение так называемых «миллениумов», они «ждут немедленного вознаграждения за любой поступок, моментальной ответной реакции» $[5$, c. 8] на свои действия. Поэтому правильный подход и учет потребностей молодёжи позволит органам власти и местному обществу наиболее эффективно использовать её энергию и потенциал.

Молодежные объединения очень часто упоминаются как один из видов социальных институтов, и это справедливо, так как деятельность молодежных организаций основана на непосредственном участии молодежи в формировании и реализации проектов силами самих молодых людей. При этом фактор самоорганизации, совместной деятельности, коммуникации, дружбы и симпатии также имеет не меньшее значение, чем само содержание предлагаемой деятельности. Со стороны же власти существует закономерный резон воспользоваться потенциалом молодёжных объединений с целью если и не взять их под контроль, то хотя бы с максимальной пользой использовать их на благо общества и государства. Тем более что, как показывают данные исследования, и среди участников молодёжных групп есть запрос на то, чтобы принести пользу обществу. Напомним, что желание принести пользу обществу в качестве мотива создания и вступления в молодёжные объединения отметил $31 \%$ опрошенных.

\footnotetext{
${ }^{1}$ При ответе на данный вопрос допускался выбор нескольких вариантов ответа.
} 
Какие это могут быть точки приложения активности молодёжных объединений? Мы попросили молодёжь дать ответ на вопрос: деятельность в какой сфере или сферах молодежных движений, объединений и групп была бы наиболее полезной для общества и города (см. диаграмму 2).

\section{Наиболее востребованные для общества направления деятельности молодёжных организаций (в процентах) ${ }^{1}$} Диаграмма 2

\author{
общественные работы \\ (волонтерство)
}

творческая деятельность

поисково-спасательная деятельность

научная деятельность

патриотическое воспитание и просвещение

политическая деятельность другое 0

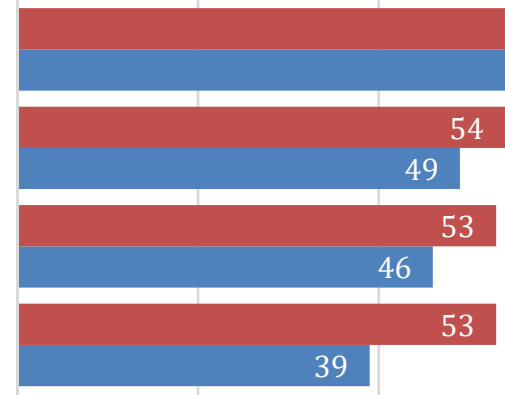

43

\section{4}

53

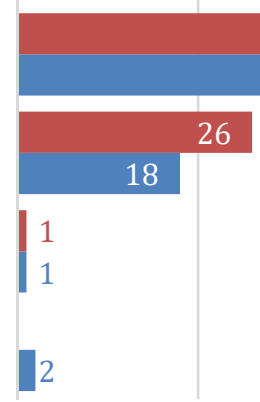

20
35

\section{6}

68

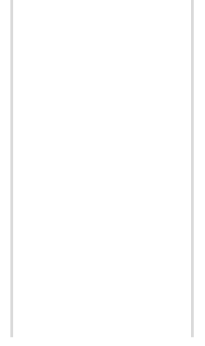

40

60

80

ш молодёжь, считающая, что молодежные организации должны приносить пользу

п молодежь в целом

Данные опроса свидетельствуют о том, что молодые люди, считающие, что молодёжные объединения создаются для того, чтобы приносить пользу обществу, видят более активное участие молодёжных организаций в жизни города и общества, нежели их сверстники. Хотя лидирующее положение с точки зрения сфер, в которых следует реализовывать потенциал молодёжи, всё тот же. Во-первых, это общественная деятельность, во-вторых, творческая деятельность, в-третьих, поисково-спасательная деятельность и, в-четвертых, научная деятельность. Патриотическое воспитание и просвещение, а также политическая деятельность завершают список. По-видимому, ярославская молодёжь досыта «наелась» мероприятиями патриотической и политической направленности.

\footnotetext{
${ }^{1}$ При ответе на данный вопрос допускался выбор нескольких вариантов ответа.
} 
Что касается участия в общественной жизни непосредственно самих членов молодёжных организаций и объединений, то такой вопрос также был задан (см. диаграмму 3).

\section{Участие молодежных организаций и движений в общественной жизни города (в процентах от числа опрошенных)}

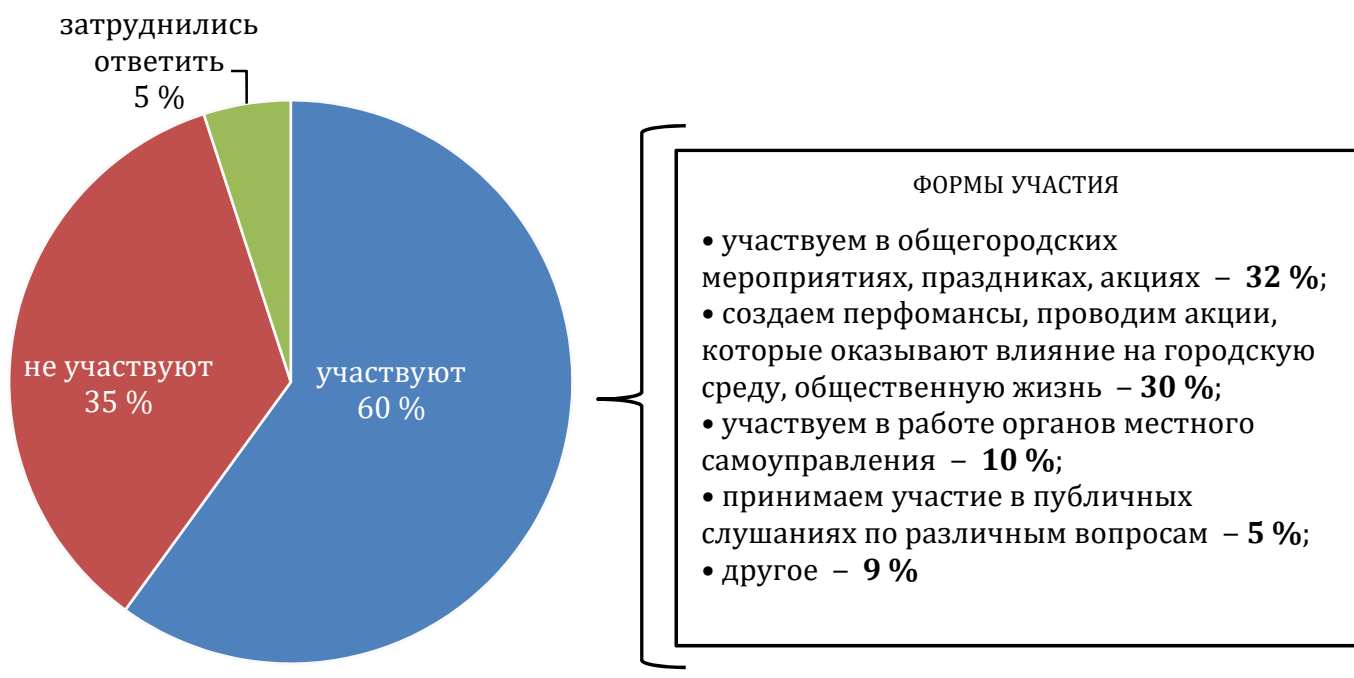

Данные опроса позволяют нам говорить о том, что почти 60 \% опрошенных подтвердили факт участия их организаций в общественной жизни города в той или иной форме. Чаще всего такое участие ограничивается вовлеченностью в общегородские мероприятия, праздники и акции (32\%), а также в создание перфомансов, которые, по мнению их участников, влияют на городскую среду и общественную жизнь (30\%).

Для тех, кто по каким-то причинам не принимает участия в общественной жизни, был также задан вопрос с целью прояснить мотивы их неучастия. Так, из тех 35 \% членов молодежных общественных организаций, которые не принимали участие в жизни города и общества, порядка $10 \%$ отметили, что, несмотря на то, что они не участвуют, им было бы интересно принять участие. Ещё 12 \% отметили, что им это попросту неинтересно, а ещё $4 \%$ посетовали, что их причина неучастия в том, что «их голос не будет услышан, 9 \% не смогли обосновать причины своего неучастия.

Таким образом, потенциально участие молодёжных организаций и объединений в общественной жизни города может значительно превышать 60 \%. Если взять в оборот «группу не участвующих, но интересующихся», а также сомневающихся (то есть тех, кто затруднился дать ответ на вопрос), то можно говорить о том, что к общественно-значимой деятельности можно попытаться привлечь от 70 до 84 \% участников молодежных объединений Ярославля. 


\section{Выводы}

В ходе исследования уровня информированности ярославской молодёжи о деятельности городских молодёжных организаций были получены следующие интересные результаты. Так, реально только каждый четвертый (24 \%) опрошенный молодой ярославец реально информирован о деятельности молодёжных общественных организаций. Современная молодёжь плохо усваивает разницу между формализованными общественными молодёжными организациями и собственными неформальными молодёжными группами и течениями. Ярославская молодёжь достаточно аполитична. В молодёжном секторе развиты и популярны такие направления, как военно-патриотическое и волонтерское. Организации данной направленности имеют очень высокий рейтинг узнаваемости. Если сравнивать формальные и неформальные молодёжные группы, то ярославская молодёжь наиболее информирована о вторых.

Показатель вовлеченности в деятельность молодёжных организаций, течений и групп в масштабах всей ярославской молодёжи невысок и составляет порядка 21-23\%. Иными словами, каждый пятый молодой ярославец в возрасте от 14 до 35 лет является участником какого-либо молодёжного объединения, движения или неформальной группы.

Главными мотивами вступления молодёжи в организации и объединения, по её мнению, являются: поиск новых знакомств (64 \%), возможность самореализации (59\%) и проведение досуга (53\%). Дополнительной мотивацией, подстегивающей молодых людей к вступлению в молодёжные группы, по результатам нашего исследования, следует признать также поиск смысла жизни и любви.

По мнению опрошенных, почти 60 \% молодёжных организаций и движений принимают участие в общественной жизни города. Чаще всего это участие ограничивается вовлеченностью в общегородские мероприятия, праздники и акции (32\%), а также в создание творческих и социально-ориентированных перфомансов (30 \%). Потенциально к общественно-значимой деятельности можно попытаться привлечь от 70 до 84 \% участников молодежных объединений Ярославля.

\section{Ссылки / References}

1. Радченко А. Ф. Молодёжь и её возрастные границы // Социология власти. 2012. № 3. C. 19-29.

2. Луц Ю. А. Общественные объединения как ресурс социальной активности молодёжи России: автореф. дис. ... канд. социол. наук. Архангельск, 2016. 26 с.

3. Возраст молодежи в России предложили повысить до 40 лет // m24.ru. URL: https://www.m24.ru/news/obshchestvo/17062019/79957 (дата обращения: 06.05.2020).

4. Государственная молодёжная политика: российская и мировая практика реализации в обществе инновационного потенциала новых поколений: науч. монография / Под общ. ред. В. А. Лукова. М: Изд-во Моск. гуманит. ун-та, 2013. 718 с.

5. Безбогова М. С., Ионцева М. В. Социально-психологический портрет современной молодежи // Интернет-журнал «Мир науки». 2016. T. 4. № 6. URL: https://mirnauki.com/PDF/35PSMN616.pdf (дата обращения: 06.05.2020).

6. Бурбаева С. Б. Развитие социальной активности молодежи в условиях общественного объединения // Мир науки, культуры, образования. 2011. № 5. С. 226-228. 
7. Власова О. В. Молодёжная субкультура как социологическая проблема // Вестник Сургутского государственного педагогического университета. 2012. № 2. С. 90-97.

8. Ильинский И. М., Луков В. А. О перспективах развития организованного молодёжного движения в России (социально-философские, социологические, политико-правовые аспекты) // Знание. Понимание. Умение. 2016. № 1. С. 5-28.

9. Астафьева В. С. Роль детских и молодёжных организаций в формировании гражданского общества // Научный вестник МГТУ ГА. 2011. № 166. С. 170-173.

10. Родина О.А. Молодёжные общественные объединения в современной России: социологический анализ эффективности: автореф. дис. ... канд. социол. наук. Екатеринбург, 2006. 26 с.

11. Кострикин А. В. Молодёжные общественные объединения как институт гражданского общества // Известия Российского государственного педагогического университета им. А. И. Герцена. 2008. № 80. С. 181-185.

12. Чаплинская В. С. Молодёжные общественные объединения как опорный институт гражданского общества // Наука и образование сегодня. 2017. № 1. С. 50-52.

13. Великанова Е. В. Роль молодежных политических общественных объединений в Тамбовской области // Вестник ТГУ. 2011. № 1. С. 149-156.

14. Бухнер А. А. Влияние молодёжных организаций и объединений на участие молодёжи в гражданском обществе // Вестник Международного института рынка. 2016. № 1 (2). C. 83-88. 